\title{
Cultivar Registration at the Arnold Arboretum 1992
}

\author{
Stephen A. Spongberg ${ }^{1}$ \\ The Arnold Arboretum, The Arborway, Jamaica Plain, MA 02130, USA
}

The Arnold Arboretum of Harvard Univ. continues to serve as International Registration Authority for cultivar names in 11 genera of ornamental woody plants, and the following notes pertain to cultivar names that have been registered at the arboretum since the last list was prepared. The 11 genera include Chaenomeles, Cornus, Fagus, Forsythia, Gleditsia, Lantana, Malus (ornamental species), Philadelphus, Pieris, Ulmus, and Weigela. Inquiries concerning the registration of cultivar names in these genera should continue to be addressed to Dr. S.A. Spongberg, The Arnold Arboretum, The Arborway, Jamaica Plain, MA 02130, USA.

Cultivar names registered during the past year include the following selections of Cornus, Gleditsia, Malus, and Ulmus.

Cornus florida 'Ozark Spring'. Registered 30 June 1992. Registrant: John C. Pair, Horticulture Research Center, Kansas State Univ., 1901 East 95th South, Wichita, KS 67233-8351, USA. This new cultivar of the flowering dogwood was selected from 125 plants grown from seed collected from naturally occurring dogwood trees growing in the Cookson Hills of Oklahoma. Originated by Ben Davis, II, of the former Ozark Nurseries, Tahlequah, Okla., 'Ozark Spring' has been introduced by John C. Pair. 'Ozark Spring' was selected for its hardiness and cold tolerance, having withstood temperatures as low as -31C. In freezing tests, Harold Pellett, Univ. of Minnesota, found that flower buds survived -30 to $-31 \mathrm{C}$. [This cultivar was published mistakenly as 'Cherokee Maiden' in HortScience 25(6):617.]

Cornus florida 'Spring Grove'. Registered 8 June 1992. Registrant: Matthew J. Vehr, 4521 Spring Grove Ave., Cincinnati, OH 45232, USA. Originated at the Spring Grove Cemetery and Arboretum, where the original plant is estimated to be about 50 years old, the plant was selected and introduced by Thomas Smith. A full description of this new selection appeared in the $15 \mathrm{Feb}$. issue of American Nurseryman [175(4):47].

$\overline{{ }^{\mathrm{T}} \text { Horticultural }}$ Taxonomist.
Cornus occidentalis 'Stinson Beach'. Registered 24 Feb. 1992. Registrant: Bertram G. Johnson, Regional Parks Botanic Garden, Tilden Regional Park, Berkeley, CA 94708, USA. This selection of C. occidentalis, originally collected at Stinson Beach, Marin County, Calif., has been previously fully described in The Four Seasons [9(1), 19911.

Gleditsia tricanthos 'Prairie Sky'. Registered 10 Feb. 1992. Registrant: Paul G. Olsen, Roseberry Gardens, Box 933, Thunder Bay, Ont. P7C 4X8, Canada. This new selection of honey locust originated at Maple Creek, Saskatchewan, Canada, around 1980, and has been named and introduced by Paul G. Olsen. 'Prairie Sky' is very upright and symmetrical in habit, but was selected primarily for its demonstrated cold hardiness; since 1980, its branches have sufferedno winter dieback, and the plant is reliably hardy in USDA Zone 3.

Malus 'Royal Splendor'. Registered 10 Feb. 1992. Registrant: Paul G. Olsen, Roseberry Gardens, Box 933, Thunder Bay, Ont. P7C 4X8, Canada. Malus 'Royal Splendor' originated as a chance seedling that was grown from open-pollinated seeds collected from Malus 'Royalty' at Roseberry Gardens. 'Royal Splendor' was selected by Paul G. Olsen, who has noted that, as with Malus 'Royalty', the leaves are purple and glossy, but the single flowers are bright pink (RHS color chart 55B) with a white center. Its fruit, moreover, are small $(\approx 1.3 \mathrm{~cm}$ in diameter) and purple. The tree's growth habit is upright with a rounded crown, and it is expected to achieve an ultimate height of $\approx 5$ m. It is hardy in USDA Zone 3.

Ulmus parvifolia 'Ohio'. Registered 5 June 1992. Registrant: A.M. Townsend, U.S. National Arboretum, 3501 New York Ave., NE, Washington, DC 20002, USA. Ulmus 'Ohio' originated at the research site of the U.S. National Arboretum in Delaware, Ohio, and has been selected and named by A.M. Townsend. 'Ohio' is a moderately vaseshaped tree with a crown similar to a more upright American elm, and its bark displays the typical lacebark quality. Its leaves have a distinct gray-red fall color, as does its fruit. Moreover, the tree is highly resistant to both Ceratocystis ulmi and to elm leaf beetle. 